\title{
CENTENARY OF THE UNIVERSITY OF MELBOURNE
}

\author{
By ProF. JOHN S. TURNER \\ Department of Botany, Melbourne
}

$\mathrm{T}$

HE University of Melbourne held its centenary celebrations during the week beginning August 13. Delegates from a hundred universities presented addresses. The oration was given by Sir Ian Clunies Ross, and fifteen honorary degrees were conferred in the new Wilson Hall. There were Vice-Regal and Government receptions, and the Council of the University gave a banquet in the Hall at the conclusion of the ceremony.

To-day the metropolitan area of Melbourne sprawls over some 200 square miles and houses $1 \frac{1}{2}$ million people, more than 60 per cent of the population of the State of Victoria. In its University there are about eight thousand staff and students. In 1840 less than half this number of people were living in the raw pioneer township on the banks of the Yarra. Twelve years later gold was found, and the young Colony began its first hectic burst of growth. The opportunities were then even greater than now. Hugh Childers, later to be British Chancellor of the Exchequer under Gladstone, and just down from Cambridge, became Auditor-General in 1852, and a year later he put through an Act to found the University of Melbourne. This was four years before the first election to the new Parliament. In 1854 Mr. Justice Redmond Barry became the first chan- cellor. The obvious site for the University, the Domain, now the centre of Melbourne's great system of parks, was then covered with the tents of migrants, and 100 acres were allotted to the University two miles out of town in almost virgin bush. Here was built the first wing of a small stone Gothic quadrangle, which served the University as its home for another twenty years.

The University made slow progress in a community of pioneers and gold-miners. During the next fifteen years it granted only a hundred degrees. Nevertheless, it was wisely served by its first administrators and teachers. In 1853 there were only four universities in Britain, and Melbourne, therefore, had an unrivalled opportunity of attracting first-rate men to its chairs. The first four professors who lived and worked in the little stone quadrangle were exceptional men. Two of them were from Ireland: Sir Frederick McCoy, F.R.S., the first professor of natural science and the founder of Melbourne's National Museum, and W. E. Hearn, the great professor of law and history. M. H. Irving (classies) was from Oxford, and W. P. Wilson (mathematies) from Cambridge. They were followed by G. B. Halford in 1863 , the holder of the first chair of the new Medical Faculty.

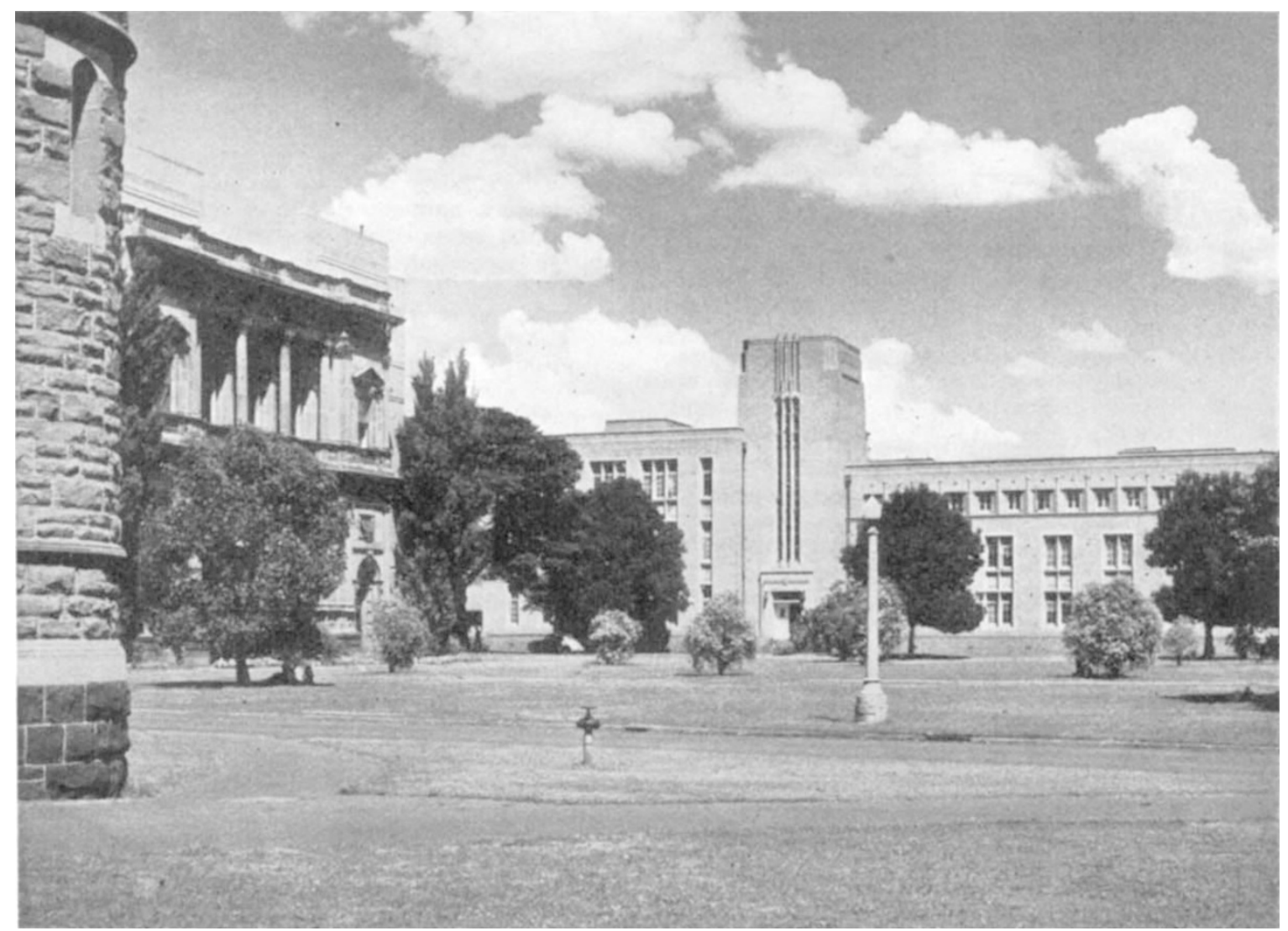

Fig. 1. The University of Melbourne. Left to right: Zoology, Commerce, Chemistry Schools 


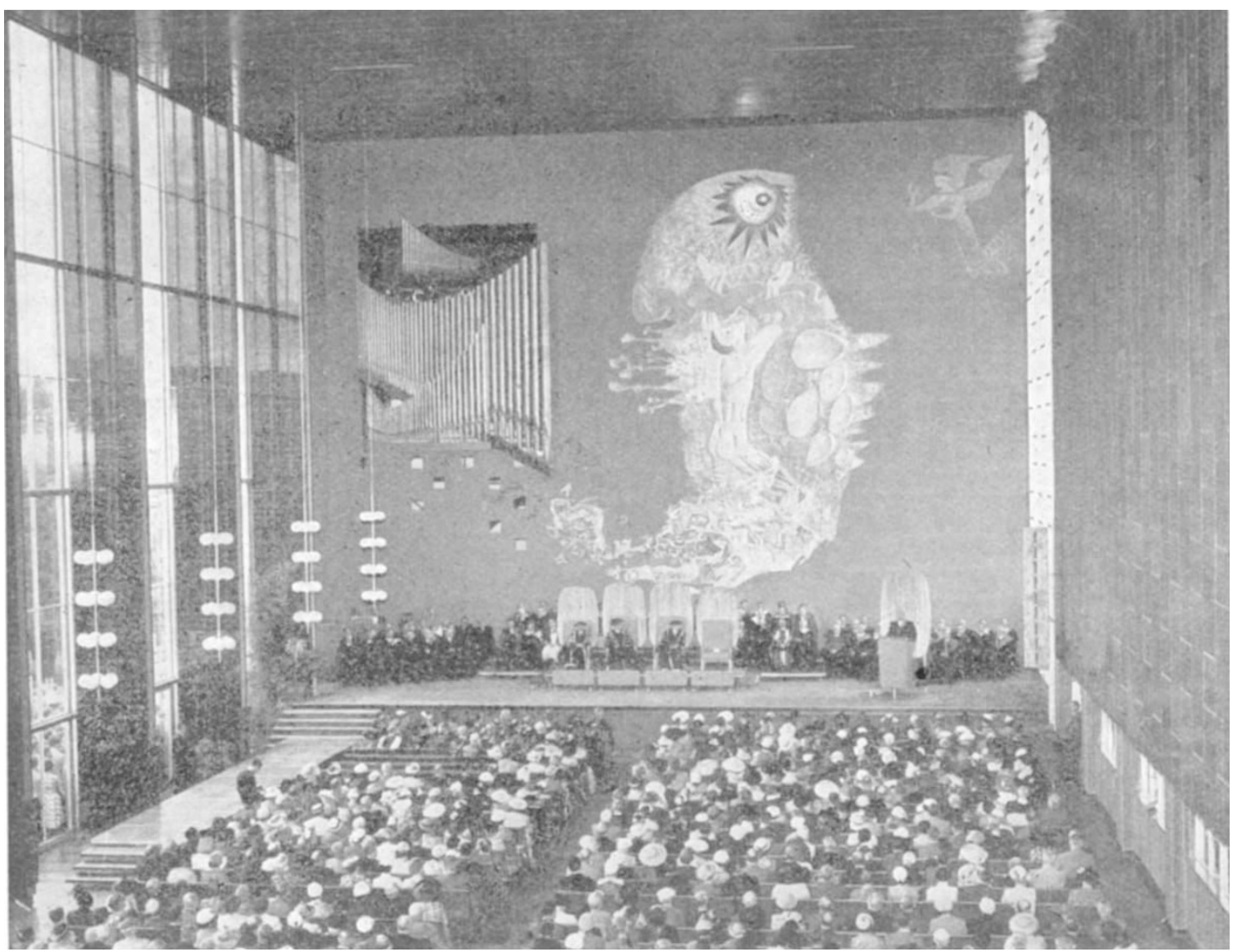

[Photo: Visual Aids, University of Melbourne Fig. 2. Wilson Hall, University of Melbourne. The Premier of Victoria, the Hon. H. E. Bolte, addressing the meeting at the opening of
Wilson Hall by the Governor, Sir Dallas Brooks

The University began its first move forward in the 'eighties. By that time most of the professorial houses were ready in the grounds-great red-brick Victorian mansions, now largely used for housing the overflowing departments. Five new professors, four of them Melbourne men, were appointed in 1882, and they were soon joined by four newcomers from Britain, who set a standard of scholarship and learning which Melbourne has consistently retained. They were T. G. Tucker (whom Cardinal Newman called the first Greek scholar of the day), David Orme Masson, chemist, Baldwin Spencer, the biologist who pioneered anthropological work on the aborigines, and Thomas Lyle, the first of a number of distinguished physicists. All three scientists became members of the Royal Society of London, and were later knighted, and their names are still remembered with affection and gratitude. The reputation they built up for the infant University attracted others, and out of a long list it is perhaps fitting to mention Sir William Harrison Moore (law), Sir Ernest Scott (history), E. J. Nanson and J. H. Michel, F.R.S. (mathematics), T. H. Laby, F.R.S. (physics), Sir Charles Martin, F.R.S. (physiology), J. W. Gregory, F.R.S., and E. W. Skeats (geology), W. C. and W. N. Kernott and H. Payne (engineering), W. R. Boyce Gibson (philosophy), G. W. L. MarshallHall (music), Sir Harry Brookes Allan (pathology), A. J. Ewart, F.R.S. (botany), W. E. Agar, F.R.S. (zoology), R. J. A. Berry and F. Wood-Jones, F.R.S. (anatomy) and L. F. Giblin (economics).

The University has been fortunate also in its administrators-it has had great legal chancellors like Sir Redmond Barry, Sir John Madden and Sir Charles Lowe, and an able succession of registrars. It is governed largely on British and Scottish lines, and although the supreme control is in the hands of a lay Council, a great deal of the government of the University is left to the Professorial Board and the Vice-Chancellor. The University made its greatest step forward into the modern period when it appointed Mr. (now Sir) Raymond Priestley as its first full-time vice-chancellor in 1936. Although he stayed only three years, his drive and energy saw the completion of the fine new Students' Union and the new Chemistry School. An inspiration to the staff, he was also instrumental in bringing town and gown together into a collaboration which resulted, under the present vice-chancellor, in the centenary appeal which raised more than half a million pounds. Priestley was followed by Sir John Medley, from Winchester and New College, Oxford. A man with wide contacts in the educational and business worlds of Australia, he brought to the University something of the grace of another period which is badly needed in an age of technocracy. He had to cope with the extremely difficult post-war period, when student numbers rose to alarming proportions. Under his 
rule, and that of his successor, Prof. G. W. Paton, an unusually friendly spirit of co-operation arose between the members of the different faculties. The University has remained well balanced in the humanities and science, and has built up exceptionally strong medical and technological faculties over the past seventy years.

As may be expected in a metropolitan university, only a small proportion of the undergraduates live in the five colleges. Four of these are church foundations, and they have played an important part in the University, largely owing to the ability of their heads, of whom the Rev. E. H. Sugden, Sir John McFarland, Dr. Alexander Leeper, Sir John Behan, Dr. D. K. Picken and Father Murphy are the best known.

The University still occupies its original site, and here are gathered twelve faculties, a staff of 427 full-time academics with 812 part-time teachers, and a student body of 7,500. The growth of the University has been largely unplanned, and the architectural styles vary from the original Gothic of the quadrangle to utilitarian red brick, Glaswegian academic, Scottish baronial, Renaissance and the plain Army hut, the fruit of two world wars. Lawns and some trees still survive from McCoy's original ambitious plantings, and there are now signs of considerable improvement. The Union, Chemistry School, Geology wing, the new Arts block and, more recently, the Beaurepaire Physical Education Centre and the magnificent new Wilson Hall (which replaces an early benefactor's Gothic Hall) are a sign of a new dignity to come. With a massive immigration and considerable inflation, the University is only slowly finding it possible to erect new departments; but the long-awaited Library is about to rise, and with it new engineering buildings and the first floors of a new Biochemistry School, the gift of Sir Russell Grimwade.

Since the Second World War the University has taken an increasing interest in the Near East, and there are some three hundred Asian undergraduates reading for degrees at present. A new college, International House, is nearing completion, and this will accommodate equal numbers of Australian and over- seas students. Several senior members of staff have travelled recently in Asian countries to advise on educational matters, and a new Department of Indonesian Studies has been set up.

The University has played a great part in the training of leading public and professional men in Australia and elsewhere. This is not the place to assess its achievements in scholarship; but it must be remembered that until recently little attempt was made to encourage indigenous research schools above the M.Sc. level. A characteristic of the young Australian is his urgent desire to see the world, and especially Britain, and this has led to a constant outward stream of graduates, mainly to Oxford, Cambridge and London. While we must be grateful to these universities for the training they have given to these men and women, it must not be forgotten that they, in their turn, have undoubtedly added to the prestige of the research schools in Britain. The Ph.D. degree was instituted in Melbourne in 1946, and now most departments are building senior research groups. This is a matter of some difficulty because of the increasing demand for our students by industry and the Government services. The future of the University is at present in the balance. It is a hundred years old, but active and vital, still growing rapidly and bursting at the seams. In spite of large annual financial grants by State and Commonwealth Governments and some splendid endowments, the University will not be able to cope with the demands which will shortly be made upon it. The State high schools are accepting six thousand new enrolments and the Education Department is building ten new high schools per annum. It must often be difficult to decide on the proper date for the foundation of a new university; but no such problem exists in Melbourne to-day. The State need's another university and it needs it urgently. The public men in Victoria are not without vision, and ambitious schemes are already in operation which will ensure the provision of power and water for a greatly increased population. At this time of centenary we confidently look to another Childers to found a second university, so that the old one may mature to its full greatness.

\title{
THE ANTIGENIC STIMULUS IN TRANSPLANTATION IMMUNITY
}

\author{
By Dr. R. E. BILLINGHAM*, DR. L. BRENT and Prof. P. B. MEDAWAR, F.R.S. \\ University College, London
}

\section{Introduction}

T 'RANSPLANTATION LMMUNITY' may be defined as the state of acquired resistance which leads to the destruction of homografts, that is, of grafts transplanted between two different members of the same species. The chemical nature of the substances that provoke it has so far defied analysis. It is widely believed, for want of clear evidence to the contrary, that only living cells can elicit transplantation immunity; and this belief appears to be upheld by the fact that an otherwise highly active suspension of living spleen cells or leucocytes loses its antigenic power after treatment in any of the following ways: heating to $48 \cdot 5^{\circ} \mathrm{C}$. for $20 \mathrm{~min}$.; drying from the frozen state; or freezing and thawing three or four times. It will be shown here that the

* Research Fellow of the British Empire Cancer Campaign. power of cells to elicit transplantation immunity depends neither up $n$ thair being alive nor upon their structural integrity in any anatomical sense; and that the antigens responsible for skin transplantation immunity are certainly nuclear substances, and probably desoxyribonucleoproteins.

We have worked with mice of two strains (domestic sublines of strains $A$ and $C B A$ ) acting as donors or recipients at will. These strains differ from each other by upwards of 10-15 genetically distinguishable antigens which affect the survival of skin homografts ${ }^{1}$. The median survival times of skin homografts transplanted from $A$ to $C B A$ mice or vice versa are as follows: $A \rightarrow C B A, 11 \cdot 0 \pm 0 \cdot 3$ days ; $C B A \rightarrow A$, $10.2 \pm 0.3$ days ${ }^{2}$. These figures refer to mice receiving homografts for the first time. A second homograft, transplanted after the rejection of a first, is destroyed within six days ${ }^{3}$ : healing is weak, 